\title{
Influence of Interaction between Higher Education Institutions and Audit Organizations on Graduates Training In Management, Economics and Finance Institute Kfu
}

Meleschenko S.S. ${ }^{a}$

Akhtyamova A.Sh. ${ }^{\text {b }}$

Gabidullina E.F.c

Ismagilova L.R.d

a bcd Kazan Federal University, Institute of Management, Economics and Finance, Kazan, 420008, Russia

\section{Doi:10.5901/mjss.2015.v6n1s3p222}

\section{Abstract}

The article is devoted to the relevance of the interaction between higher education institutions and target employers within new Russian education standards. The paper considers the effectiveness of existing work model of the Kazan (Volga Region) Federal University with audit firms and proposes further improvement of colloboration effiency.

Keywords: the interaction of higher education institutions, target employers, audit firms, students' professional orientation, the quality of graduates training

\section{Introduction}

In accordance with impelemtation of Federal State Education Standards for the third generation (hereinafter - the standard or FSES III), the interaction with the employer is an important aspect of Bachelor training. The standard requires the active involvement of employers' representatives as external experts in the education process. A similar standard for Master's training defines the proportion of the employers involvement to be not less than $20 \%$ of all the instructors, they must take the operating executives or senior manager positions in the relevant organizations. New Federal State Education Standards for bachelor's and master's degrees, the so-called III +, which entered into force on September 1, 2014, specify that the employers involvement in the education process should be carried out in the form of continous assessment, interim assessment, as well as review of assessment tools [3]. Table 1 shows the comparative characteristics of the standards related to the employers involvement.

Table 1. Changes in Federal State Education Standards as to employers involvement requirements

\begin{tabular}{|c|c|c|c|c|c|}
\hline \multirow{2}{*}{$\begin{array}{l}\text { Name of } \\
\text { the } \\
\text { Standard }\end{array}$} & $\begin{array}{l}\text { Quality criteria (Requirements to } \\
\text { be met by employers involved) }\end{array}$ & \multicolumn{2}{|c|}{$\begin{array}{l}\text { Quantitative criteria } \\
\text { (the number of employers } \\
\text { representatives) }\end{array}$} & \multicolumn{2}{|l|}{ Areas of involvement } \\
\hline & Bachelors & Bachelors & Masters & Bachelors & Masters \\
\hline FSES III & $\begin{array}{l}\text { Acting managers and senior } \\
\text { employees of relevant } \\
\text { organizations - traget employers } \\
\text { as external experts }\end{array}$ & $\begin{array}{l}\text { Not less } \\
\text { than } 5 \% \\
\text { Of all } \\
\text { insrtuctors }\end{array}$ & $\begin{array}{l}\text { Not less than } \\
20 \% \text { Of all } \\
\text { Professors }\end{array}$ & $\begin{array}{l}\text { Ongoing progress } \\
\text { monitoring procedures, } \\
\text { interim assessment }\end{array}$ & $\begin{array}{l}\text { Assess education process } \\
\text { quality in general and the } \\
\text { work quality of individual } \\
\text { Professors }\end{array}$ \\
\hline FSESIII+ & $\begin{array}{l}\text { Employers as external experts } \\
\text { whose work experience in the } \\
\text { occupational area is not less than } \\
3 \text { years }\end{array}$ & & & \multicolumn{2}{|c|}{$\begin{array}{l}\text { Continous assessment, interim assessment. } \\
\text { Varifying assessment tools. } \\
\text { Evaluation of the education process content, } \\
\text { organization and quality in general and that of the } \\
\text { certain disciplines, internship and the work of } \\
\text { individual instructors and Professors }\end{array}$} \\
\hline
\end{tabular}

Aim of the study is to develop a phased cooperation model of higher education institutions and employers. The study is 
conducted in Economics on the basis of Kazan (Volga Region) Federal University (hereinafter - KFU). The audit organization both regional and international ary considered to be employers.

\section{Theory}

In order to comply with the FES III + requirements in attracting employers as external experts it is necessary to organize the system of interaction on the basis of long-term contracts that would provide a permanent impact on the quality of students proficiency. The approach is based upon the contacts of the Institute of Management, Economics and Finance KFU (hereinafter - the Institute) with audit firms. Institute has established strong relationships with the leading audit firms that are involved in training Bachelors and Masters in Economics majoring in "Accounting, analysis and audit". The results of the interaction of KFU with audit firms are shown in Picture 1.

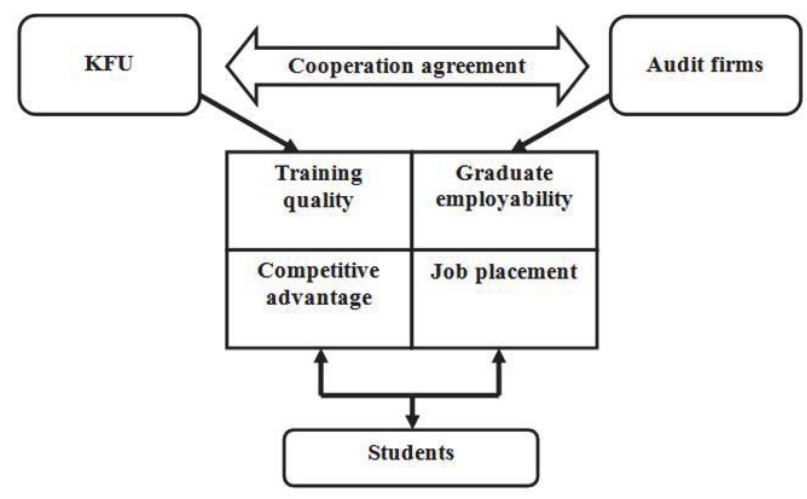

Picture 1: The results of the interaction of KFU with audit firms

The interaction lies on the cooperation agreements without finance involvement. In accordance with the agreement the audit firms participate in the education process, provide conditions for internship with an idea of graduate employability [1].

Each party is able to successfully achieve the results expected of the interaction. That is, getting audit firms managers involved in the training process, Institute meets the requirements of education standards and of the business community. The audit organizations having the access to the undergraduates and postgraduates training process could select the most promising candidates and test them during internship or advise on curriculum practical training. According to audit firms such while-training monitoring of the undergraduates and postgraduates has a positive impact on the employment policy.

The Institute has a cooperation agreement with the world's four largest audit firms (the Big Four) PricewaterhouseCoopers, Ernst \& Young, KPMG and leading regional audit organizations FBK -Volga region and AUDEX (the cooperation with the longest history is with the Kazan office of PricewaterhouseCoopers. The first agreement was signed in 2008).

The existing interaction structure of KFU and audit firms is shown in Figure 2.
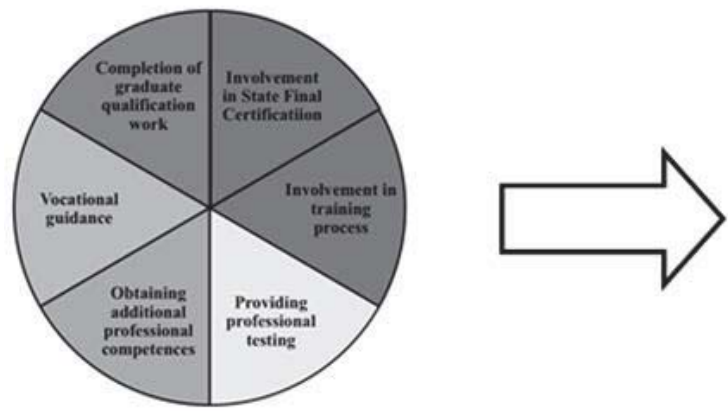

Graduates employability

Figure 2: The existing interaction structure KFU and audit firms 
Interaction with audit firms currently is carried out in several directions.

The first and the most traditional is participation in the Graduates State Final Certification. Representatives of these organizations act as legally competent members of the State Certification Commission. Based on the results, such participation from year to year secures high level of graduates knowledge majoring in Accounting.

The second direction is straightforward involvement in the education process. The plan of cooperation is developed and updated yearly with each audit organization and approved at the beginning of the academic year. Participation of audit organizations specialists in the syllabus of each course is agreed in advance with the Professors and includes a preliminary discussion of the issues the auditor is going to deliver. The students informed about the opportunity can interact with highly qualified specialist and ask the questions of their concern. The practical orientation of such studies reveals new aspects of the course and makes students interested in their future profession and encourages students to extend knowledge and consequently improve their performance [4].

The third direction of interaction is conducting proficiency testing of students whose major is accounting. Systematically since 2009 PricewaterhouseCoopers has been conducting such testing inviting those students who voluntarily want to have their proficiency assessed. The testing attracts from 150 to 200 students annually. Since 2014 AUDEX and FBK-Volga region, two regional audit companies, joined in provision of the testing.

Hence, it was decided to go forward and make the test mandatory for all graduates with the assisstance of the KPMG Kazan office staff and using their evaluation tools that contain a digital test to determine the ability to operate general economic categories and conduct accounting and analytical operations, computational and analytical task and an essay in English. The result is that in 2014293 Masters and Bachelors majoring in Accounting were tested which makes $85 \%$ of total graduates number. And 52 of them fully complied with the KPMG starting requirements which represents $17.7 \%$ of the students tested. This was found to be a positive test result, but more attention, in our opinion, should be given to the training analysis of the rest $82.3 \%$ of students.

In a more practical context the assessment of performance by the professional community allows to ascertain the strengths and weaknesses in the students training and, on this basis, to modernize training process [5].

The fourth direction is that students receive additional professional competence in the framework of audit firms. In this regard, recently there has been a variety of forms and approaches. The Big Four provides our students majoring in accounting with the opportunity to have internships while studying. This allows the students not only to get an insight of the auditor's profession, but furthermore be motivated to continue study when they understand the value of the knowledge acquired. The AUDEX and FBK-Volga region provided students with opportunities to work on probation in 2013-2014 academic year and shape the selected students to the needs of the companies and thus target them at work in these organizations. As a result, the students received certificates which became an essential part of their professional portfolio [2].

The fifth direction of interaction is associated with an undergraduates professional orientation. Here, it is important to note the role of PricewaterhouseCoopers Kazan office. Over the last few years they have been organizing «Feel like an auditor», a business game, with second-year students, which is very important as during the first two years of study all students enrolled at the Institute have general curriculum without specialization/ majors. After the second year, students face the problem of major determining. This game is the best tool for making the right choice.

The sixth direction is participation of audit firms in the completion of graduates final qualifying work. While writing a paper on the topics related to the audit the students are coordinated and advised by the audit organizations and provided with papers, documents and advice. AUDEX and FBK-Volga region give the final review on the papers.

All these directions of cooperation are the results of sustainable realization and may have natural continuation. Such a conclusion can be drawn from the fact that it all began with an invitation of audit firms employees to participate in the State Final Certification and deliver certain lectures. Today's cooperation has reached a new level the main feature of which is the annually planned consistency [6].

\section{Results}

The main result of the Institute and audit firms interaction is recognition of graduates by the auditors alumni community which is evidenced by the successful graduates employment with audit organizations. For example, the KPMG Kazan office where, from the very beginning of its operation, $70 \%$ of staff is our graduates. The most striking example is the performance of the PricewaterhouseCoopers Kazan office, where 106 graduates are currently working and by September 36 graduates representing $10 \%$ of the class have received a job offer this year.

Analysis of interaction allows to form a phased cooperation model (Figure 3), which will visually represent the most efficient sequence of joint actions for the successful collaboration with any employer. 


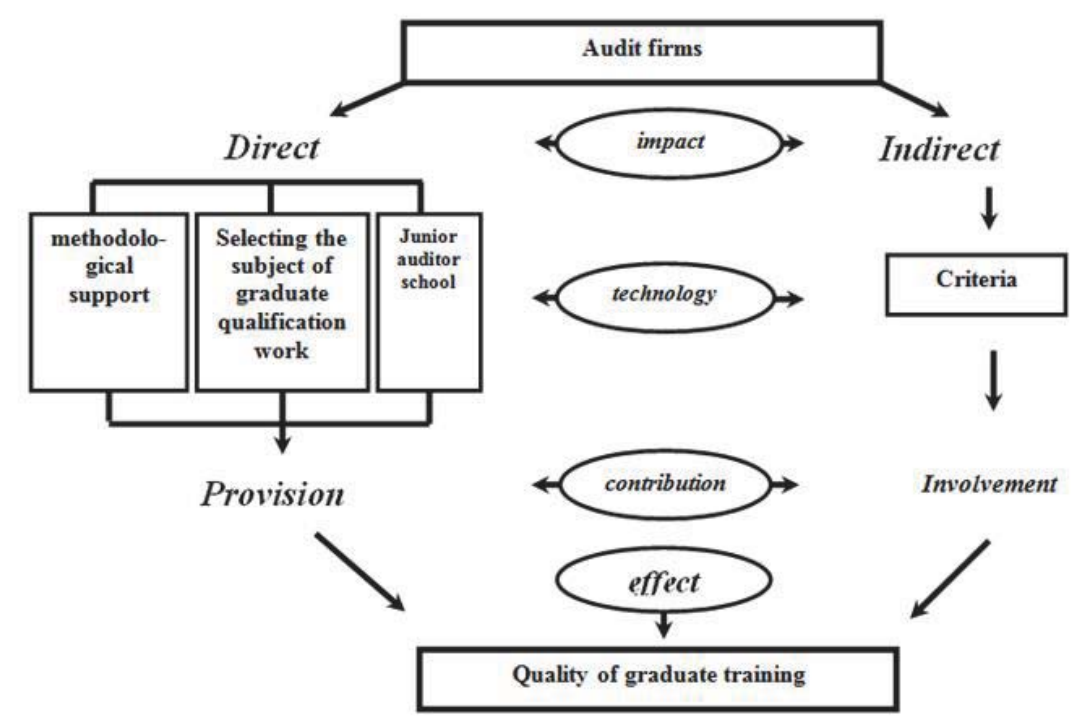

Figure 3: Model of the audit firms impact on the quality of graduates training

The other result of the interaction was the shift in the Institute education policy implying the fact that the graduates need specialization to work with audit organizations. In this regard, within the framework of Bachelors in Economics (major in Accounting, analysis and audit) the third year students will have an opportunity to choose audit as a major by taking relevant elective courses. In addition to general professional courses they will study the practical audit, information technology audit, taxation and international accounting standards, bank accounting in-depth [7]. The list those of proposed for specialization has been agreed with the audit firms which heavily participated in curriculum and made it relevant to the preparation of their future employees [8].

It should be noted that the aspects where interaction requires more effort could

be divided into direct and indirect impact.

The technology to implement direct impact on training quality for audit organizations can be identified the following:

- firstly, it is the auditors' participation in the formation of methodological support of the curriculum. It is advised to form the training-methodical commission with the participation of audit firms and faculty members to validate the practical orientation of syllabuses. Practical orientation is the most vulnerable aspect, as teachers do not always have a practical experience. In this respect, providing teaching aid auditors facilitate methodological support and make the training content realistic to the audit practice;

- secondly, the participation of auditors in forming subjects list of final qualifying papers. This will make the work more practically significant for audit organizations and attractive for students and can also be implemented by the proposed training-methodical commission;

- thirdly, students who are most interested in the auditing could get training at Junior Auditor School to be jointly established on the basis of the Institute. Students of the School will be considered as qualified candidates pool.

All of the above will ultimately ensure the quality of training.

To define the indirect impact of the audit firms activities on the training quality, identified were criteria for assessing the audit organization performance which characterize its social activity.

Ultimately, this participation will also have an impact on the training quality in the audit field.

\section{Conclusion}

Given the growth rate on the audit services market it is found essential to separate major Audit from the major Accounting, analysis and audit in Economics.

Therefore given the interaction experience of the university and audit firms and to strengthen the influence on the auditors training process it is proposed to introduce the criteria characterizing the audit organization involvement that may link social and professional activities of the audit organization into performance rating. The criteria proposed to evaluate the audit organization participation in training process are given in Table 2. 
Table 2. Evaluation criteria of the audit organization participation in training process

\begin{tabular}{|c|l|l|}
\hline $\mathrm{N}$ & Criteria & Characterization \\
\hline 1 & methodological support & $\begin{array}{l}\text { percentage of audit firms employees who participated in the } \\
\text { development and review of training materials of the curriculum }\end{array}$ \\
\hline 22 & participation in the curriculum development & number of syllabus developed with the participation of the audit firms \\
\hline 33 & $\begin{array}{l}\text { consideration the issues important for the audit } \\
\text { organization in the final qualifying work }\end{array}$ & $\begin{array}{l}\text { number of final qualifying papers written by order of the audit } \\
\text { organization }\end{array}$ \\
\hline 44 & advice on the final qualifying work & $\begin{array}{l}\text { proportion of audit firms employees advising on the final qualifying } \\
\text { work }\end{array}$ \\
\hline 55 & $\begin{array}{l}\text { participation in the National Certification } \\
\text { Commission }\end{array}$ & $\begin{array}{l}\text { proportion of audit firms employees participating in the State Final } \\
\text { Certification as Chairmen or members of the Commission }\end{array}$ \\
\hline 66 & $\begin{array}{l}\text { students' training and internship with the audit } \\
\text { organization }\end{array}$ & $\begin{array}{l}\text { number of students in relation to the number of acting employees / } \\
\text { auditors in audit organization }\end{array}$ \\
\hline 77 & $\begin{array}{l}\text { conducting research and/or practical training of } \\
\text { students }\end{array}$ & $\begin{array}{l}\text { number of students who had internships and received certificates } \\
\text { from audit organization }\end{array}$ \\
\hline 88 & participation in the education process & $\begin{array}{l}\text { the number of class hours / hours of distance learning, held by the } \\
\text { staff of audit organization }\end{array}$ \\
\hline 99 & $\begin{array}{l}\text { professional orientation of students aimed at } \\
\text { promoting the auditors image }\end{array}$ & having a work plan and its implementation \\
\hline 110 & graduates employability & institutes graduates involved in the above mentioned activities \\
\hline 111 & participation in collaborative research & $\begin{array}{l}\text { The funds of contract research, the share of audit organization } \\
\text { employees involved in the research }\end{array}$ \\
\hline
\end{tabular}

The fact that the rate of auditors participation in the education process has positive effects is demonstrated by a survey of second-year students choice of major - 148 people out of 230 expressed a desire to get training in audit considering Accounting, analysis and audit. Such an increase in the popularity of the auditor as a profession is a direct result of interaction.

\section{References}

Yelinek, K., Coffta, M. 2013. The value of graduate internships in creating online tutorials // College and Research Libraries News 74 (11), pp. 558-576

Safiullin, N.Z., Gafurov, I.R., Safiullin, L.N., Odintsova, J.L. 2014. Education system of the world: Modern trends // Mediterranean Journal of Social Sciences 5 (18 SPEC. ISSUE), pp. 91-94

Safiullin, N.Z., Gafurov, I.R., Safiullin, L.N., Odintsova, U.L. 2014. Modern information resources in education // Mediterranean Journal of Social Sciences5 (12), pp. 113-116

Jackson, D. 2014. Testing a model of undergraduate competence in employability skills and its implications for stakeholders // Journal of Education and Work27 (2), pp. 220-242

Bednar, L. 2012. Teaching case using a research in technical and scientific communication class to teach essential workplace skills // IEEE Transactions on Professional Communication 55 (4), 6287618, pp. 363-377

Ferguson, J., Collison, D., Power, D., Stevenson, L. 2011.Accounting education, socialisation and the ethics of business // Business Ethics 20 (1), pp. 12-29

Nagimova, A.M., Safiullina, F.R. (2014). Combination of university training with employment among Kazan' students. Sotsiologicheskie Issledovaniya, (4), pp. 121-124.

Kavetskyy, V., Baydetskyy, P. 2010 Trends of social and professional student orientations formation // Economics and Sociology 3 (2), pp. 135-138

Jackson, D., Sibson, R., Riebe, L. 2014 . Undergraduate perceptions of the development of team-working skills // Education and Training56 (1), pp. 7-20

Fraser, K., Richardson, J., Karpathiou, V. 2014. Employability skills: Differing requirements and perceptions of regulators, accrediting bodies, students, academics and employers for coursework masters business (IT) programs // International Journal of Pedagogy and Curriculum 20 (2), pp. 27-44

Safina, D., Podgornaya, A. (2014). Mobbing as an organizational phenomenon impeding implementation of changes. Mediterranean Journal of Social Sciences, 5 (18 SPEC. ISSUE), pp. 187-192

Daniels, J., Brooker, J. 2014. Student identity development in higher education: Implications for graduate attributes and work-readiness // Educational Research 56 (1), pp. 65-76 